Vol. 1, No. 1, June 2021, Pp. 25-46

ISSN: 2693-9797 (online)

\title{
Voter Fraud's False Advertisers: Partisanship and Preventing Another Kansas Interstate Voter Registration Crosscheck Program
}

\author{
Alexander Siegal, Columbia University
}

\begin{abstract}
When people move between states, it is necessary for states to clean up their voter registrations to match the voter's current location; this involves states sharing voter data among themselves. One of these data-matching operations experienced particular success - the Interstate Voter Registration Crosscheck Program (“Crosscheck”), based out of Kansas. It shouldn't have: it had a flawed methodology, a more cost-effective rival, and a partisan strategic orientation. This paper researches the correlation between state partisan control and Crosscheck membership, and finds strong associations between Republican state legislative control and membership in the program - however, it also finds a handful of instances of participation by Democratic states. It finds an additional regional bias toward midwestern and southern states, likely due to proximity to Kansas. Seeking to explain these outliers, the remainder of the paper explores the administrative costs and benefits of using Crosscheck, discusses the possibility of Democratic communication failures, and offers solutions.
\end{abstract}

\section{Background}

One of the most unique day-to-day challenges that American election registrars face occurs when people move between states. Since election administration is devolved to the state level under the United States' federal system, and since the states are equal in power to one another, there is no central body that has the legal prerogative to track all the people who move from one state to another and are registered to vote in each. ${ }^{1}$ According to a 2012 Pew report, this administrative gap resulted in an election administration landscape where 2.75 million Americans were present on more than one state's voter rolls (Inaccurate, Costly, and Inefficient 2012). These duplicate registrations usually happen out of negligence, not malice-for example, there's not necessarily a formal impetus for

people to cancel their prior registrations when they move away-but the vulnerability has also permitted some very sparse instances of double voting, a type of voter fraud. To be clear, a voter is more likely to be struck by lightning than to commit fraud (Levitt 2007), but the weakness technically does exist, and it has therefore become a viable political talking point, if not a realistic one.

Indeed, there are more pressing issues in the election administration sector than double voting, and there is a wide swath of opportunities to more significantly improve the quality of voter registration lists, like eliminating typographical errors, making sure changes of address are accurately

\footnotetext{
${ }^{1}$ Technically, the federal government has the legal capacity to undertake this task; however, it has not done so.
} 
updated, and allowing voters to update their registrations online. Eliminating errors in the voter rolls increases voter participation, enables the optimal allocation of poll workers, and also improves security (Shaw, Ansolabehere, and Stewart 2015). However, raising the specter of double voting is much more politically sensational than these prosaic mechanical enhancements, and so it nets disproportionate attention. This was particularly the case during the 2020 election, when unfounded voter fraud allegations were a key component of the constellation of lies told by the Trump camp, contributing to the insurrection at the Capitol on January 6th, 2021 (c.f. Gerhart 2021).

Voter registration cross-checking between states first became feasible after 2002, when Congress mandated that states would need to centralize, standardize, and digitize their voter rolls under the Help America Vote Act (HAVA). Thanks to the development of these digital systems, voter rolls had suddenly become easily shareable, creating an opportunity (Esau 2017) to solve the problem of duplicate registrations. HAVA also mandated that states solve this problem and clean up their voter rolls.

In 2005, therefore, the office of the Kansas Secretary of State - the chief administrator of the state's elections - worked with its counterparts in neighboring Iowa, Missouri, and Nebraska to begin a collaborative project that would come to be known as the Interstate Voter Registration Crosscheck Program (IVRC or "Crosscheck"). The program was a mechanism for states to cross-compare their voter rolls in order to eliminate duplicate registrations, one of the first of its kind. ${ }^{2}$

In thirty-eight states, however-Kansas among them - the Secretary of State (or an equivalent office $)^{3}$ is elected in a statewide partisan contest, and the winners of those elections are therefore usually ambitious political operators. In the case of ruby-red Kansas, that means that Crosscheck was administered by a Republican political aspirant for eleven of the twelve years that it operated. ${ }^{4}$ Deep partisan ties - in both this office and its counterparts in other statesare especially troubling in this instance because the post-2000 world marked the rise of "voter fraud politics," a Republican messaging strategy created to overinflate Americans' perceptions of the prevalence of voter fraud (c.f. Ellis 2013). In doing so, the GOP would build support for more stringent voting requirements that disproportionately obstruct Democratic voters' access to the ballot. This strategy was executed using a number of vehicles, including the Justice Department. (Minitte 2010, 4-5, 94; Gitlin and Weiser 2017).

One particularly germane component of the early voter fraud campaign involved inflating statistics. In 2004, leading Republicans nudged "Thor" Hearne to create and lead a new conservative nonprofit called the American Center for Voting Rights (ACVR), whose primary mission was to implement voter ID laws (c.f. Hasen 2012). During its short lifetime, ${ }^{5}$ the ACVR

\footnotetext{
2 There were some other contemporary regional compacts in the mid-2000s.

${ }^{3}$ Secretary of the Commonwealth in some states, or the lieutenant governor in a few others.

${ }^{4} 2006$ - 2009: Ron Thornburgh (R), who considered a Senate run but dropped out. 2010: Chris Biggs (D), was appointed by the governor and lost election. 2011 - 2018: Kris Kobach (R), who since has run for governor, a Senate seat, and now for attorney general.

${ }^{5}$ The organization folded just before it would have had to begin reporting its revenue per federal requirements. (Minnite 2010, 14).
} 
released a 74-page report that claimed to unveil widespread voter fraud in the 2004 election - to the tune of around 300,000 potential fraudulent votes. Hearne repeatedly reiterated this claim in congressional testimony and in media interviews. Scholar Lorraine Minnite worked through their data and debunked that number; the number of potential fraudulent votes that she could confirm was actually around 185 (Minnite 2010, 12-14, 102). Despite the mistruths, the strategy nevertheless successfully shifted the national debate: in 2006, Indiana became the first state to pass a strict voter ID law (Lee and Smith 2016).

\section{“Red" Flags}

This recent history demonstrates an observable pattern - a contemporary context into which to place Crosscheck. The system began as a bipartisan project in 2005 , but was directed by the usually-Republican Secretary of State of Kansas. Crosscheck's use as a partisan tool took center stage under the leadership of Secretary Kris Kobach, who also regularly champions laws requiring strict photo identification and the presentation of proof of citizenship in order to vote (Lowry and Woodall 2017).

When he took over Crosscheck, Kobach envisioned a national expansion of the thenregional program and made it a priority, stating once that "I have taken it under my wing and want to build it as one of my personal missions," (Rothschild 2014). That he did: over Crosscheck's lifetime, a total of thirty-five states involved themselves with the program at one point or another, ${ }^{6}$ and concurrent usage peaked at twenty-eight states. It ceased operating after 2017, when the Department of Homeland Security discovered that Crosscheck had insufficient data privacy protection standards. The program was later indefinitely suspended by a federal court for the same reason (Hegeman 2019).

Just as the Bush Justice Department had controversially done in the past, Kobach sought to draw publicity by announcing voter fraud investigations and prosecutions. Frustrated by professional prosecutors' unwillingness to take aggressive action ${ }^{7}$ against the handful of people he had caught double voting - frequently older people who simply misunderstood the law and voted in local elections in two different places where they owned property-Kobach successfully induced the Kansas legislature to give him prosecutorial powers in 2015, after many years of lobbying. He was the only secretary of state in the country to have that power (Lefler 2019). In the remaining four years of his tenure, he used his independent authority to pick up unprosecuted voter fraud cases and open new ones. He even hired someone to be the office's new "criminal investigator." Because voter fraud is in fact

\footnotetext{
${ }^{6}$ Those states are Alabama, Alaska, Arizona, Arkansas, Colorado, Florida, Georgia, Idaho, Illinois, Indiana, Iowa, Kansas, Kentucky, Louisiana, Maine, Massachusetts, Michigan, Mississippi, Missouri, Minnesota, Nebraska, Nevada, New Hampshire, New York, North Carolina, Ohio, Oklahoma, Oregon, Pennsylvania, South Carolina, South Dakota, Tennessee, Virginia, Washington, and West Virginia. Texas is labeled as a signatory and passed legislation in 2015 to begin the process of joining, but the state appears to have never successfully participated in Crosscheck before it was suspended.

7 "Betty and Steven Gaedtke were two of the first people Kobach charged... County attorneys in Kansas declined to prosecute the Gaedtkes, seeing the double voting as an honest mistake. But in October 2015, a month before the five-year statute of limitations expired, Kobach charged them each with three misdemeanor counts of 'voting without being qualified."' (Berman 2017).

${ }^{8} \mathrm{He}$ had no formal experience in such a role (Zeff 2019).
} 
very rare (Goel et al. 2020), Kobach only prosecuted fifteen people, winning nine convictions. Ironically, the defendants were usually confused Republican voters with multiple residences (Lefler 2019).

\section{Politicizing Statistics}

Just as the American Center for Voting Rights strategically overestimated claims of fraudulent voting by several orders of magnitude, Crosscheck was designed in such a way as to report a sensational ancillary result that can be easily misconstrued as the number of duplicate registrants discovered by the program. This output was called the "number of potential duplicates," and during Crosscheck's final five years of operation, that number usually hovered around 7 million, from a total of around 100 million voter files. Importantly, it was not the final result of the total filtering process: it was just an intermediate result generated along the way. Kobach's office and allies in conservative advocacy groups reported that number to the media, cranking out headlines like "Study: Seven Million Voters Registered in Multiple States" (Kirby 2017). Intentionally publicizing that artificially overinclusive statistic results in inflated public perceptions about voter fraud's prevalence in the United States. Just as Thor Hearne injected incorrect numbers into legislative testimony to sway lawmakers in the mid-2000s, people like Alan Vera, chair of a county GOP "ballot security committee" in Houston, incorporated Crosscheck's "potential duplicates" into similar testimony to Texas state legislators:

This is not a hypothetical problem but a very real one. Last week, my former colleague, Catherine Engelbrecht of True The Vote, revealed the results of a nationwide study of about 28 states already taking part in the
Crosscheck program. In those 28 states, there were 6.9 million voters registered to vote in at least two of them. The situation bears some investigation. (Texas Senate 2015)

Sure enough, Texas would later pass the bill for which he was advocating, SB 795, which enabled the Texas Secretary of State to participate in the interstate sharing of voter files and was intended to enable Texas to join Crosscheck.

\section{Crosscheck's Controversial Mechanics}

States that participated in Crosscheck sent their digital voter registration data to the Kansas Secretary of State, whose office operated the program free of charge. Staff in Kansas then ran the eponymous cross-check, with the preliminary match criteria being voters' first names, last names, and dates of birth (Office of the Kansas Secretary of State 2017). This group was the "potential duplicates," and as an elementary understanding of demography and statistics would lead one to imagine, there were a great many so-called "duplicates," and the vast majority were false positives (Goel et al. 2020, c.f. McDonald and Levitt 2008).

Again, it should be noted that this number was never supposed to be the final result. Sensibly, state officials were then encouraged to also cross-reference the data with middle names, suffixes, the last four digits of voters' Social Security numbers, and some other data like residency history; when this was done correctly, the crosscheck was formally complete.

As it grew, this system itself drew controversy along partisan lines as well. Generally, Democrats and civil rights groups were the ones who criticized it, and they did so on two distinct but interrelated grounds. First, the preliminary match criteria — on 
their own-were racially biased, because it is more common for members of racial and ethnic minorities to share first and last names with one another. In 2014, for example, one in seven Black voters was a preliminary match, compared to one in eleven white voters. For Asian Americans and Latinos alike, the number was one in eight (Palast 2014).

Secondly, Crosscheck facilitated illegal voter purges. Consequently, civil rights groups and Democrats feared illegal purges of those minority voters who were disproportionately targeted by the preliminary criteria. Technically, both issues would have been negligible if all of the secondary matching criteria were always used properly and purges were done cautiously. Indeed, purges do not seem to have been the direct intent of the programthere were specific instructions to follow the voter protections outlined in the 1993 National Voter Registration Act (Office of the Kansas Secretary of State 2017). However, for unclear reasons, these steps did not always happen. Improper voter purges were conducted in Virginia in 2013, where the Republican-led State Board of Elections (SBE) provided insufficient guidance to registrars and improperly vetted residency history, purging legitimate voters just before a tense statewide election (Brater 2013), and in Idaho's Ada County in 2014, where the office didn't even check for matching middle initials before canceling voters' registrations. Similarly, in 2017, Republicans in Indiana attempted to enact a law that would have leapfrogged the voter protections set out in the National Voter Registration Act and immediately canceled voters' registrations if they were flagged by Crosscheck and county registrars agreed; that law was soon struck down in federal court. Democrats, of course, spoke out in opposition when these purges happened (c.f. Barakat 2013).
These illegal purges were rare, and it's unlikely that the (mostly Republican) officials conducting the purges and operating Crosscheck had a high degree of intentionality in their selection of the specific matching criteria and their fidelity to those criteria. Incompetence is a very persuasive rival explanation: in Virginia, for example, registrars indicated that the instructions were confusing; sure enough, some registrars followed the protocol correctly, and others didn't. An additional layer of partisan machination is not necessarily implausible - the Virginia SBE used some curious strong-arming on a couple of reluctant county registrars (Nolan 2013), for example, and the aggressive purges that Crosscheck normally facilitated have always been known to disproportionately risk affecting more vulnerable populations (Pérez 2008) — but such an investigation here is unlikely to be analytically useful. Instead, the important takeaway for the remainder of the paper, which will investigate a partisan split in the state-by-state adoption of Crosscheck, is that the controversy itself existed, and that it fell along partisan lines. That controversy's observability after 2013 should have further disincentivized the adoption of Crosscheck in states where Democrats held power.

\section{Summary}

Kobach claims that Crosscheck was a bipartisan program. Mechanically, though, Crosscheck offered demonstrably one-sided benefits for the Republican Party.

Specifically, it provided ammunition for their voter fraud messaging strategy, which is intended to limit Democratic voters' access to the ballot and ultimately prevent or hinder the election of Democrats to political offices. Additionally, while the program's built-in statistical exaggeration may not be easily observable, the outspoken opposition to Crosscheck by Democrats in certain states 
after illegal purges or similar chicanery is readily available in news reporting, and the increasing controversy surrounding the program in the mid-2010s should have mitigated against some of the possible information problems that Democratic state legislators may have faced. From a policymaking perspective, one would therefore hope that Democrats would have roundly opposed participation in the program; otherwise, the checks and balances of the party system may not be functioning appropriately on this issue.

\section{Testing Partisan Alignment}

If Crosscheck was in many ways a partisan tool, as I have outlined, it should have been adopted in a partisan way. It is odd, then, that some very Democratic states like Washington and New York signed up for Crosscheck, even if it was only for short periods of time. This is especially true after 2012, when the Electronic Registration Information Center (ERIC) - a rival, apolitical, and more professionally-run data cross-checking program administered by the Pew Charitable Trusts - was established and began a national expansion of its own. If state Democrats, against their better political interests, signed up for a GOP-aligned Crosscheck program, that indicates potential failures within the political system: problems with information delivery to state legislators, for example, or insufficient resolve or attention from the national party organization. More importantly, such a breakdown suggests a dramatic policy failure; after all, an insecure, inefficient, and controversial interstate data matcher should not have been allowed to exist in the first place. Remedies might include federally subsidizing ERIC membership or even incorporating the system at a federal level under the Election Assistance Commission in order to spur ERIC's expansion, thereby crowding out future undesirable alternatives similar to Crosscheck.

\section{Data, Variables, and Methodology}

I use regression analysis to test for an observable partisan split in state-by-state usage of Crosscheck, and to more fully develop a scholarly understanding of what factors may have predicted participation in the program. Since it requires a distinctly higher level of commitment to take the affirmative step of joining the program for the first time, as opposed to simply remaining in the program after already joining, I measure participation in two ways:

1. annual participation in Crosscheck's sweeps (inivrc), and 2. instances where new states join
Crosscheck (ivrc1styr).

Finding the exact date that states officially joined Crosscheck is difficult: the memoranda of understanding (MOUs) between secretaries of state that denote each state's entry into the program are, like other information about Crosscheck, very difficult to find in public records (Minnite 2015). Given that difficulty, the first year of IVRC membership serves as a proxy variable. Both dependent variables are binary and categorical. After a state's first year in Crosscheck, ivrclstyr is eliminated from consideration.

I test these two dependent variables against three exogenous independent variables that represent categories of partisan control: one tracks the party affiliation of the secretary of state, a second tracks that of the governor, and a third tracks party control of the legislature. The first two are also binary categorical variables; on the other hand, legislative control is a trichotomous variable. Three ascending categories are necessary because mixed control of a 
legislature would give a party the power to obstruct legislation but not to pass legislation of their own. These data can be found at the National Conference of State Legislatures. All variables are delineated in Table A below.

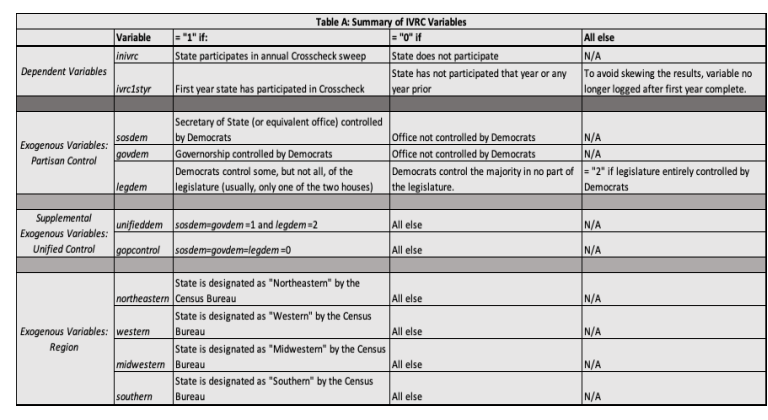

Analysis is conducted using a series of heteroskedasticity-robust panel probit regressions and their reported marginal effects. First, I test for the state power center for which partisan control (if any) is most correlated with that state's membership in the respective program, and compare the results. Then, to control for a potential regional bias - Crosscheck was originally a Midwestern regional program, and Kansas and its neighbors lean Republican-I input the Crosscheck finding into a region-byregion breakdown with interaction terms, to test for any significant differences there and better pinpoint policy suggestions. Finally, since it is possible that state action on voter roll integrity has a partisan skew, these analyses are repeated with ERIC for a supplemental comparison.

The Crosscheck data analyzed here was obtained by an investigative advocacy group called Leave Crosscheck, part of the
Indivisible activist network, and placed online as a resource (Leave Crosscheck 2017). It is a limited dataset and only robust between 2009-2017. ${ }^{9}$

\section{Summary Data}

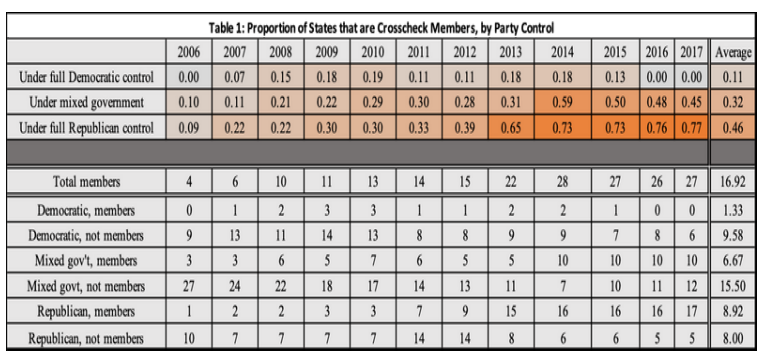

Table 1 tracks the partisan breakdown of Crosscheck membership using the unified partisan control variables. Rather than using the raw quantity of states, since that measurement is not easily comparable among different years when power changes hands, Table 1 tracks the proportion of certain categories of states that are Crosscheck members, split by party control. The data are presented as a heat map for convenience, and the raw numbers are also listed for reference.

The prima facie findings in Table 1 are predictable but fairly dramatic. By 2017 , under Kobach's leadership, Crosscheck counted most Republican states among its members, and about half of all states under mixed government. Equally interesting is the drop-off in Democratic and mixedgovernment participation after a 2014 peak, perhaps highlighting the increased polarization of the program in its later years. On average, Republican-controlled states

\footnotetext{
${ }^{9}$ The IVRC was originally just one of multiple regional data-sharing projects that Kansas worked on in the 2000 s. Eventually, by 2009, they had been consolidated into the IVRC. The data prior to the consolidation is therefore not necessarily comparable to the data after the consolidation. While the condition of this dataset is not perfect, I'm nevertheless immensely grateful for it, as it has been notoriously difficult to obtain records about the program from Kansas in the past (Palast 2016). While it is fair to question the reliability of the data given that Indivisible is explicitly opposed to Crosscheck, portions of the data do conform to other reports made by Crosscheck directly (e.g. Kirby 2017).
} 
were four times more present in Crosscheck than Democratic-controlled states. The 2013 and 2014 spikes in Republican and mixedgovernment membership are also quite noticeable, and upon further investigation may indicate there was an energetic recruitment drive by Kobach at the culmination of his first term.

\section{Probit Analysis: Partisan Control}

To obtain a better understanding of the associations between Crosscheck membership and the control of different state power centers, I conduct a series of panel probit regressions ${ }^{10}$ designed to probe those relationships. They are designed to predict the marginal changes in the probability of a state's being a Crosscheck member given partisan control of certain power centers. Because there is very high correlation between the control of one branch of government and the control of other branches of government, I have separated out each relevant power center (secretary of state, governor, legislature) into its own regression to test which fits best on its own.

Additionally, I have segmented the data into two time periods. The first, 2012-2017, is a period of time in which Crosscheck had a nonpartisan competitive rival (Pew's ERIC), while 2009-2011 is a period of time before that was the case. 2012 also marks Kobach's first year leading the program, and with it, a major escalation of Crosscheck's partisan alignment.

Table 2 tracks six regression outputs that examine the relationship between control of each power center (treated as exogenous) and annual membership in Crosscheck. The $d y / d x$ column represents the marginal impact, in percentage points, on the likelihood that a state is a Crosscheck member given Democratic control of a certain power center. In other words, it tracks the individual effect of partisan power on the probability of Crosscheck membership, isolated from other variables.

For the main period, 2012-2017, all three regressions produced significant results. The best fit, contrary to the hypothesis, comes not from control of the secretary of state's office but instead from control of the legislature, probably due to the fact that joining an interstate data matching program typically requires the passage of enabling legislation. Legislative control also bears the strongest fit in terms of marginal impact. Regardless, all three are significant and substantial effects, and these are all strong evidence which indicate a clear partisan imbalance in the program.

For the supplementary earlier period where Crosscheck operated without a competitor, 2009 - 2011, no variable was associated with a statistically significant marginal impact. These differences between the two time periods may support a hypothesis that Crosscheck membership became more polarized after the nonpartisan alternative ERIC entered the picture; they also may suggest a need for better early data ${ }^{11}$ between 2006 and 2008 to supplement the $2009-2011$ period.

\footnotetext{
${ }^{10}$ Panel probit regressions used Gaussian random effects and delta-method standard errors. Future studies might benefit from a more rigorous fixed-effects logistic regression analysis that also incorporates variables like the professionalization of a state's legislature, the quantity or quality of its staffing, its election administration structure, and so on.

${ }^{11}$ This would involve digging up the year-by-year membership of the other regional cross-checking programs Kansas conducted in the South before it decided to consolidate everything into the IVRC.
} 


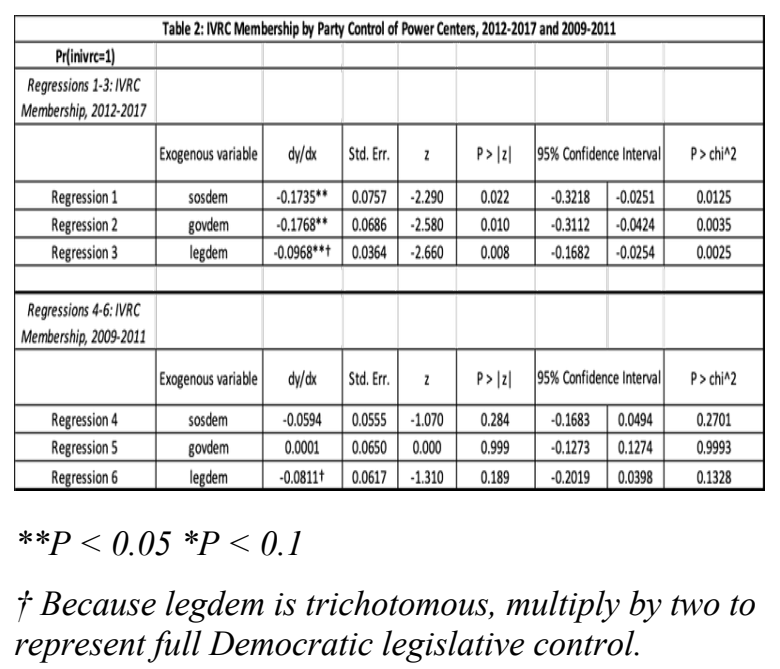

Finally, Table 3 tracks these same exogenous variables across the same time period but attempts to pinpoint a relationship between control of power centers and the first year of Crosscheck membership Similar to the prior table, Democratic legislative control has the best-fit and strongest negative association with joining Crosscheck. As for the supplementary early 2009-2011 period, no result was significant; again, this could be a sample size problem, but it also could very well indicate that partisan control had a negligible effect on a state's joining Crosscheck before 2012.

\begin{tabular}{|c|c|c|c|c|c|c|c|c|}
\hline \multicolumn{9}{|c|}{ Table 3: IVRC New Entries by Party Control of Power Centers, 2012-2017 vs 2009-2011 } \\
\hline \multirow{2}{*}{\multicolumn{9}{|c|}{$\begin{array}{l}\text { Regressions } 7-9: 1 \\
\text { rew } \\
\text { new entries, } 2012-2017\end{array}$}} \\
\hline & & & & & & & & \\
\hline & Exogenous variable & $d y / d x$ & Std. Err. & 2 & $P>|z|$ & \multicolumn{2}{|c|}{ 95\% Confidence Interval } & P>chinz \\
\hline Regression 7 & sosdem & -0.0905 & 0.0579 & -1.560 & 0.118 & -0.2039 & 0.0229 & 0.1192 \\
\hline Regression 8 & govdem & $-0.1147^{*}$ & 0.0648 & -1.770 & 0.077 & -0.2417 & 0.0124 & 0.0836 \\
\hline Regression 9 & legdem & $-0.066^{* *+}$ & 0.0600 & -2.270 & 0.023 & -0.2540 & -0.0188 & 0.0417 \\
\hline \multicolumn{9}{|l|}{$\begin{array}{l}\text { Regressions 10-12: IVIC } \\
\text { new entries, } 2009 \text {-2011 }\end{array}$} \\
\hline & Exogenous variable & $d y / d x$ & Std. Err. & 2 & $p>|z|$ & \multicolumn{2}{|c|}{$95 \%$ Confidence Interval } & $\mathrm{p}>\mathrm{chin} 2$ \\
\hline Regression 10 & sosdem & -0.0269 & 0.0471 & -0.570 & 0.568 & -0.1191 & 0.0653 & 0.5744 \\
\hline Regression 11 & govdem & 0.0203 & 0.0433 & 0.470 & 0.639 & -0.0645 & 0.1052 & 0.6222 \\
\hline Regression 12 & legdem & $0.0127^{+}$ & 0.2524 & 0.500 & 0.614 & -0.3672 & 0.0622 & 0.6182 \\
\hline
\end{tabular}

$* * P<0.05 * P<0.1$

$\dagger$ Because legdem is trichotomous, multiply by two to represent full Democratic legislative control.

\section{Takeaways}

Both the summary data and the more indepth regressions suggest that Crosscheck state membership became significantly partisan in the period after Kobach took the helm of the program. Table 1 takes a birds- eye view and shows a spike in partisan adoption starting in 2013; Tables 2 and 3 confirm this finding and point to legislative control in particular as being the most direct predictor of a state's choosing whether or not to join Crosscheck.

\section{Controlling for Regional Bias}

Crosscheck began in 2006 as a regional program in the Midwest between Kansas, Nebraska, Iowa, and Missouri, and expanded from there, starting with neighboring states. Because the center of the country is generally more conservative than its coasts even after accounting for partisan control (c.f. Frank 2007, Mann 2006, Young 2013), this regional bias may have a nonrandom impact on the correlation of partisanship with usage of the Crosscheck program. The geographically-driven phenomenon of policy diffusion-where certain laws and ideas move between neighboring jurisdictions as their leaders learn from and imitate one another (c.f. Shipan and Volden 2008) —also implies that Crosscheck membership may have spread in this nonrandom pattern; for example, the program itself was even started at a midwestern election administration conference. Similarly, neighboring states are one of the more common destinations for those voters moving out of a particular state, meaning that the existing members are incentivized to urge their neighbors in particular to join Crosscheck.

Tables 4 and 5 report the marginal effect results of another panel probit regression. This regression selects legislative control as the independent variable to represent partisan control, incorporates Census Bureau-defined regional categorical variables, and establishes some interaction terms for the purpose of accounting for the regional bias. The final results of that test are tallied in Table 5: the relevant marginal 
effects were tabulated together. ${ }^{12}$ All four sums were jointly statistically significant, and the results do display a fairly striking regional bias within Democrats' Crosscheck membership. In the Midwest and the South, Democratic control of the legislature is associated with only around a 40 percentage point decrease in the likelihood of Crosscheck membership; in the Northeast and West, that gap is around 60 percentage points.

\begin{tabular}{|c|c|c|c|c|c|c|}
\hline \multicolumn{7}{|c|}{ Table 4: IVRC membership by region and legislature control (2009-2017) } \\
\hline Regression 13 & & & & & & $P>\operatorname{chin}^{2} 2=0$ \\
\hline Variable & $d y / d x$ & Std. Err. & $z$ & $P>z$ & $95 \%$ Confid & nce Interval \\
\hline legdem & $-0.1890^{* *+}$ & 0.0663 & -2.85 & 0.004 & -0.3190 & -0.0590 \\
\hline northeastern & $-0.3666^{* *}$ & 0.1275 & -2.88 & 0.004 & -0.6164 & -0.1168 \\
\hline western & $-0.2711^{*}$ & 0.1585 & -1.71 & 0.087 & -0.5818 & 0.0396 \\
\hline southern & -0.1002 & 0.1424 & -0.70 & 0.481 & -0.3792 & 0.1788 \\
\hline northeasternXlegdem & $0.1228^{*}$ & 0.0719 & 1.71 & 0.088 & -0.0181 & 0.2637 \\
\hline westernXlegdem & 0.0577 & 0.0863 & 0.67 & 0.504 & -0.1115 & 0.2269 \\
\hline southernxlegdem & 0.0794 & 0.0713 & 1.11 & 0.266 & -0.0604 & 0.2191 \\
\hline
\end{tabular}

$* * P<0.05 * P<0.1$

+ Because legdem is trichotomous, multiply by two to represent full Democratic legislative control.

NB: midwestern is omitted on account of multicollinearity.

Table 5: IVRC membership by region and legislature
control, cumulative marginal effects (2009-2017)

\begin{tabular}{|c|c|c|}
\hline Regression 13 & Marginal \\
effect & $\mathrm{P}>\mathrm{F}$ \\
\hline \hline $\begin{array}{c}\text { Northeastern state, } \\
\text { Democratic legislature }\end{array}$ & $-0.622^{* *}$ & 0.0007 \\
\hline $\begin{array}{c}\text { Western state, } \\
\text { Democratic legislature }\end{array}$ & $-0.591^{* *}$ & 0.0004 \\
\hline $\begin{array}{c}\text { Southern state, } \\
\text { Democratic legislature }\end{array}$ & $-0.399^{* *}$ & 0.0000 \\
\hline $\begin{array}{c}\text { Midwestern state, } \\
\text { Democratic legislature }\end{array}$ & $-0.378^{* *}$ & 0.0071 \\
\hline
\end{tabular}

$* * P<0.05 * P<0.1$

\section{Comparison: Electronic Registration Information Center}

It is also important to control for the possibility that interstate cross-checking is an issue that naturally attracts Republicans more than it does Democrats. If that were the case, one could expect to see a partisan split in any cross-checking program, not just the Kansas Crosscheck. Mimicking Table 1, Table 6 explores the year-by-year proportions of states - sorted again by partisan control - that were members of Crosscheck's rival program, ERIC. The pattern is almost the inverse of Crosscheck's, with strong early adoption from Democratic states and even stronger adoption from mixed-rule ones, perhaps after ERIC had become better-known as the more reliable method of protecting voter access and had become more comprehensive in scope. Clearly, though, Democrats appear sufficiently committed to interstate data matching, implying that they did choose to veer away from Crosscheck in particular.

Most spectacular is the sudden jump in Republican participation starting in 2018, after Crosscheck was shut down by a federal court. That number is still increasing. While further investigation is needed, this seems to fairly safely imply that ERIC and Crosscheck were indeed rival substitutes, with Democrats generally avoiding Crosscheck and Republicans generally prioritizing it.

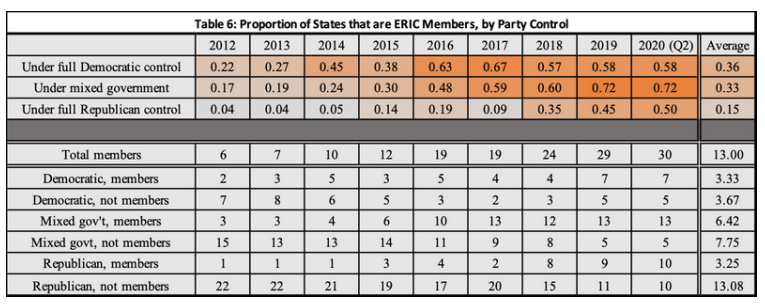

\footnotetext{
${ }^{12}$ E.g. for northeastern Democrats, the marginal impacts of legdem*2, northeastern, and northeasternXlegdem were summed. The exception is midwestern, which is omitted on account of multicollinearity and already factored in as a baseline.
} 


\section{Diagnosing Problems and Identifying Solutions}

In the first portion of this paper, I have demonstrated that Crosscheck had a number of partisan aspects to it that should have been visible to contemporary observers, even before the program was incorporated into the Republican national platform in 2016. Crosscheck's results consistently reinforced a broader and well-known Republican voter fraud messaging strategy, and the system drew flak in the media for enabling massive illicit voter purges. I then determined that adoption of the program was in fact done in a partisan manner, especially in the period after 2012 .

There were, nevertheless, a number of outlier states that joined Crosscheck despite having Democrats in some level of power. Four states were under full Democratic control when they joined Crosscheck; another eighteen had some amount of mixed government. In the remaining portion of this paper, I seek to understand other factors that may have driven such states to sign onto this program, given its observably partisan nature. Obviously, the actual utility is the ability to clean outdated registrations from voter rolls. Democratic state administrators still receive the benefit of this utility, but at the cost of bolstering Republican voter fraud messaging, which ultimately results in lost Democratic votes.

There are a number of potential explanations for this, of course. They all have to do with adjusting that cost-benefit equation: if the benefit of joining outweighed the cost, then it is rational for Democrats to have joined Crosscheck. I will focus on two. For one, there is the simple possibility that the Crosscheck program just had a very high administrative utility relative to its price tag. Another possibility is that state actors were not properly informed on the issue. This is unlikely to be the case, especially with the secretaries of state, but may be an investigable concern for state legislators or even governors.

The intent behind undertaking this investigation is to understand the policy failures that led to the growth and success of Crosscheck within the realm of American election administration. An analysis of those failures will then lead to a discussion of possible solutions.

\section{Is Crosscheck Administratively Useful?}

The first explanatory variable to consider is, of course, the basic administrative utility of Crosscheck. If the program were an administrative necessity, and the only one available, then Democrats might naturally feel obligated to sign up, despite its partisan alignment. The short answer is that the program is not very useful, but despite its clunkiness, Crosscheck could have been relatively useful as a means of obtaining other states' voter rolls for the purposes of comparison-especially if there's no other way to obtain the necessary records.

Experts have used colorful phrases like "remarkable naivety" (Huseman 2017) and "childish methodology" (Palast 2016) to describe the analysis that Crosscheck performs. The "potential duplicates" data that it sends to member states has a false positive rate over ninety-nine percent (Goel et al. 2020), and scrubbing that data for actionable results requires a large amount of manpower from state election administrators. Texas's director of elections anticipated having to hire an outside contractor for the sole purpose of processing Crosscheck's data, for example (Texas Senate 2015). Massachusetts cited the "significant amount of time and resources required on the part of the local election 
officials" and "the relatively low number of confirmed matches" as reasons for its departure from the program (Bruzek 2017). The problem was so bad that some Crosscheck member states never even bothered using the data. Here are some other criticisms from state administrators.

Kentucky, which confirmed it never used the data: "On the surface of it, it sounds like an okay thing to do. But then you start participating, and the data is not useful," (Cameron 2018).

New York: "There was no guarantee [Social Security numbers] would be private and majority of records were inaccurate," (Ibid).

Oregon: "We left [Crosscheck] because the data we received was unreliable," (Palast 2016).

In other words, while the program might be advertised as "free" by Kansas, and while it is true that Kansas does not charge states a nominal fee to perform the data swaps, there is still certainly an implicit non-monetary cost to using Crosscheck, in the form of a large staff time commitment.

Inefficiencies and partisan machinations notwithstanding, though, the basic premise of Crosscheck's interstate data matching is still valuable. The following is a case analysis from New Hampshire. After President Trump made a false claim about voter fraud in the state, state officials began an investigation and incorporated Crosscheck into that project. Crosscheck told New Hampshire officials that there were 94,610 "potential duplicates"- those who shared a first name, a last name, and a date of birth with someone outside of the state. Seeking to uncover double voters in particular, New Hampshire Secretary of State Bill Gardner's office removed from consideration all those who had not been flagged as having voted in both locations, bringing the list down to 4,579 files (DiStaso 2018). Next, staff had to filter out those from the file who had differing listed middle names, middle initials, and suffixes, bringing the number down even further to 955. 813 more were removed from consideration based on differing Social Security numbers, an external search for differing middle names (the Crosscheck data fields were incomplete), voter roll checklist errors, and some other circumstantial considerations like deaths. Finally, of the remaining 142 files, the Secretary of State was able to forward 51 to the state attorney general's office for more investigation. The other 91 were caught in administrative limbo at Gardner's office because other states had not sent in the information required for cross-referencing (Ramer 2018). Two years after the investigation was completed, the program has netted five successful prosecutions - mostly elderly Republicans, just like in Kansas-with two more pending (Hayward 2020).

Gardner, the longest-serving secretary of state in the country and a moderate Democrat who controversially joined the short-lived and Kobach-led Presidential Advisory Commission on Election Integrity, said to reporters that

This is valuable... That is exactly the kind of thing that I was hoping that the president's integrity commission was going to do at the federal level... It's a daunting task to try to make the effort that we did to narrow it down. Some released that initial information and were embarrassed by it. We were going to explain from the beginning how we did this.

(DiStaso 2018) 
It was indeed daunting - even for a very small state like New Hampshire. The inspection of Crosscheck data was part of a broader investigation that took 817 work hours. ${ }^{13}$ Nevertheless, Gardner's insistence on the value of the program - combined with his outspoken advocacy for a federallevel cross-checking program and his willingness to enter into additional regional compacts - implies a serious need for an expansive nationwide data-matching program. If Crosscheck were the only such program, it would still have a significant relative utility, since there would be no other vehicle to undertake the kinds of investigations and cleanups that $\mathrm{New}$ Hampshire undertook.

\section{A Rival Program}

Starting in 2012, however, Crosscheck was no longer the only way to undertake a nationwide interstate voter roll cleanup project. On an administrative level, then, state actors should therefore have had relatively little incentive to enter this program in particular, at least from the perspective of utility.

As has been mentioned, the Pew Charitable Trusts partnered with seven states to launch the Electronic Registration Information Center (ERIC) in 2012. Thirty states now use the program. ${ }^{14}$ To put it briefly, ERIC is a universally-acclaimed (Stegmaier and Lindback 2017), nonpartisan, more professionally-run program that operates continuously rather than annually and uses a wide variety of data, like DMV and USPS records. It offers unregistered people a chance to register instead of only prompting the cancellation of voter files. It also provides information about within-state address changes, duplications, and deaths, which Crosscheck does not. The Research Triangle Institute conducted a 2013 study of ERIC in comparison with Crosscheck and reported that

Every state official we interviewed was confident that the ERIC matching process was superior to any efforts their states had undertaken or might do in the near future. Officials from Colorado and Virginia explained that while their participation in the Kansasled "interstate compact" also had value, it was more time consuming, generated many false matches that required further processing, and could not provide as much functionality as ERIC. Each interviewee was convinced that ERIC's contextual matching system used to connect multiple files is more accurate than any process they could have implemented independently. This is mainly because of the sophisticated fashion in which it allows for small or predictable variations in names, birthdates, and addresses. (Bland and Burden 2013, 22)

Furthermore, as opposed to the administrative burdens imposed by Crosscheck, "none of the interviewees reported that ERIC was a significant or problematic draw on their staff time or other nonfinancial resources," (Bland and Burden 2013, 23).

\footnotetext{
13 The exact time spent with Crosscheck in particular is not available; however, Crosscheck was a major part of the investigation.

14 Texas is the most recent to join.
} 


\section{But a Lower Relative Price Tag-Maybe}

As a tool, ERIC is clearly superior to Crosscheck. However, it also costs money up front. ERIC has a one-time membership fee of $\$ 25,000$, and annual dues range between $\$ 25,000$ and $\$ 50,000$, depending on the size of a state's population. RTI's research did find that costs were a "salient concern" in some states - though "not a pressing issue" for most - and cited an official who "complained that the by-laws shifted the costs too much to larger states such as his," (Bland and Burden 2013, 23). Cost sensitivity seems to have been more of a deterrent for Republican states than Democratic ones, which aligns with traditional expectations between the two parties. For example, California's former secretary of state, Debra Bowen, did not mention cost as being a deterrent to joining the program; rather, she argued against joining ERIC (as well as Crosscheck) because she had concerns about sharing voters' data (Miller 2014). On the other hand, Texas's director of elections entered legislative testimony in 2015 indicating his preference for Crosscheck by echoing the concern about cost:

We have been in conversation with Kansas, as well as with the ERIC program, and I believe that this bill would give us sort of permission to do either one. However, ERIC would cost money that we don't currently have in our budget, so probably what we would do is the Kansas Crosscheck. (Texas Senate 2015)

He testified that it would be cheaper to hire contractors to parse Crosscheck's returns.
Similarly, the proposed bill did not require a fiscal note, meaning that joining Crosscheck could be achieved within the existing budget; it is very unlikely that the additional circa $\$ 75,000$ cost for Texas to join ERIC would not have required a note. As seen here, explicit costs do have the ability —at least rhetorically - to successfully deter consideration of a superior program like ERIC.

\section{A Conclusion on Administrative Cost- Benefit}

ERIC is an impressive tool, with a good reputation and a wide range of voter list maintenance functions that assist state administrators in most aspects of that task and do not cost a significant additional amount of staff work time. Crosscheck is the opposite: it is burdensome, has a toxic reputation, and is geared toward a limited amount of voter list maintenance functions - those that involve purging voters and targeting the very limited threat of double-voting fraud. ${ }^{15}$ While ERIC does cost money, Crosscheck's label as a "free" program is misleading and imposes its own set of costs, albeit smaller, optional ones.

However, as Secretary Gardner commented, Crosscheck can have value. That value was much higher, relatively speaking, before ERIC was launched or encompassed many states in its database: in 2014, for example, Crosscheck had twenty-eight members, while ERIC had ten. The possible explanation that Democratic states joined Crosscheck as a point of administrative necessity is therefore indeed viable, certainly until around 2016, when ERIC's membership began to hit a critical mass. Since ERIC is likely far more valuable, per

\footnotetext{
15 That's without mentioning the data privacy protection lapses like sharing voter files through unencrypted emails to dozens of recipients, and placing them on an unsecure server-which are not the focus of this analysis - that got Crosscheck suspended in the first place; obviously, those negate any administrative utility of the program.
} 
dollar expended, than Crosscheck is, and since most states said ERIC's cost concerns were "not pressing," it is unlikely that in the long-term states would have had any administrative incentive to stick with a program like Crosscheck.

\section{Information Problems}

The second potential explanation for the presence of non-Republican outliers in Crosscheck's membership is a lack of relevant knowledge on the part of state actors. This question is harder to treat because of the impossibility of proving a negative; as such, this section is more of a footnote.

Let us return to Texas. In the committee hearing on the 2015 bill to join Crosscheck, the state Democratic party sent its legislative affairs director, Glen Maxey, to register their opposition to the bill. He had correct information:

We would much prefer our state to use the ERIC system, because we get cleaner data back. Our concern is this bill is specifically mandating us to use the Kansas system because it uses the title Interstate Voter Registration Crosscheck... We want to make sure these are "hard matches." (Texas Senate 2015)

The state legislators acting on his suggestions, though, seem to not have been as well-briefed. The vice chair of the committee holding the hearing, an experienced Democratic Texas state senator named Rodney Ellis, asked an illustrative follow-up:

So, Mr. Maxey, if those issues can be worked out, then are you for the bill? I'm wondering if the Senator were to accept a provision so that the Secretary of State decides whether you use-I think you referred to it as the Kansas system or somebody else's system-I don't know if he will, but I'll find out. (Texas Senate 2015)

Ellis eventually voted no, but the bill passed with only limited opposition from both Democrats and even adjacent advocacy groups like Common Cause, who stated that they were willing to accept legislation that enabled Texas to join ERIC, Crosscheck, or both.

There are two major information problems that occurred in this case. The first came from the state Democratic Party and its representative, who maintained that they would prefer the state to avoid Crosscheck due to its reputation for enabling purges of voters, and, if they were going to use Crosscheck, to at least install safeguards to prevent purges. This is all valid, but Maxey did not successfully convey the broader administrative downsides to Crosscheck or even the national voter fraud messaging problem, both of which might have been more convincing counterarguments to Crosscheck membership; as a result, even experienced senators like Ellis had weaklydeveloped impressions of the legislation at hand.

The second information problem derives from the first, and rests with national rather than state Democrats. By adding new names to the system, each state that joins Crosscheck enables new matches everywhere in the country, compounding the size of the program's "potential duplicates" exponentially. An increase in the size of that number would then have ramifications for the nationwide voter fraud debate in that it would further enable Republican attempts to expand voting restrictions across the country. Texas, with its large size and 
substantial minority populations, would have fueled an enormous increase in that misleading number, and the ideal checks and balances of the party system should have impelled national Democrats to lean on Texas Democrats to oppose the measure more than they did.

However, election administration is a famously abstruse and frequently neglected topic in American politics. Expecting perfectly-informed action from legislative and political actors - most of whom are generalists - is usually not reasonable. Nevertheless, it has still been possible for Democratic state actors to mobilize properly (if sometimes unsuccessfully) against Crosscheck-style legislation. As a counterexample to the Texas case, Indiana's Republican-led government recently passed legislation in March 2020 that blocks the state from participating in any voter datamatching organization that requires the payment of dues (i.e. ERIC); instead, they intend to create their own replica of Crosscheck, called the Indiana Data Enhancement Association (IDEA). Indiana Democrats, uniquely informed on this debate after state Republicans pushed through a Crosscheck-based voter purge law in 2017 that was overturned by the courts, opposed this new bill, SB 334, on a strict party line, unlike the experience in equallyred Texas.

These information-delivery nitpicks may lie primarily in the field of political strategy, but they are also crucial to the policy ecosystem at hand. If it is the case that state party organizations are unable to effectively cohere against bad election administration policy, then that points to federal intervention as a potential policy solution. However, if more aggressive federal intervention remains unlikely, better political counter-mobilization strategies within and between states must be implemented in the near term to prevent a resurgence of a Crosscheck-style program.

\section{Recent Developments}

The majority of this paper was composed in June of 2020. Between then and now, election administration and voter fraud have become objects of household discussion, with many Republicans and particularly the Trump wing of the party drawing a surge of misguided attention to the issue and arguably leveraging it to incite the violence that occurred at the Capitol on January 6, 2021. John Kingdon's (1995) seminal book on policymaking notes that for legislative action to be taken on an issue, three streams of action must align: the "policy" stream, where entrepreneurial experts develop solutions in their areas of focus; the "political" stream, where politicians signal their willingness to work on a given issue; and the "problem" stream, the most unpredictable of the three, where the general public identifies a certain condition in society as a problem. In regard to problem recognition, the insurrection at the Capitol was a major focusing event, demonstrating a severe crisis of confidence in election administration (if an unsubstantiated one). One of the silver linings of that riot may be the creation of a window of opportunity for election administration reform, as the topic is taken up by the problem stream alongside favorable ongoing developments in the political and policy streams.

Normally, the federal government does not pay significant attention to the nitty-gritty problems in election administration, as the burden of conducting the elections falls on states and localities. Congress generally takes a reactionary approach. Calls for more federal funding - for upgrading vulnerable machines, taking pandemic-related precautions, expanding the poll worker pool-typically go unheeded until after a 
crisis. This was the case in 2002, when

HAVA was passed after the disastrous 2000 election. 2020, where pandemicpreparedness funding was sparse, vote-bymail was hastily established, and the incumbent president sowed doubt about the results, ought to be another such wake-up call.

There have already been positive developments regarding increased federal involvement in the particular issue of interstate voter data matching, but they are small. The flagship For the People Act (H.R. 1) includes a measure formally establishing a degree of collaboration with the ERIC system. It specifically amends the National Voter Registration Act to recognize the system as a mechanism for voter roll maintenance, while also forestalling the conduct of purges based on interstate crosschecks within six months of an election, a reasonable safeguard after the 2013 experience in Virginia and some more recent angling by conservatives to use ERIC to prematurely purge voters in Wisconsin (c.f. Johnson 2021). Under the existing bill, other interstate data matching is allowed, and importantly, there is no specific material encouragement to join ERIC.

The federal government could and should go farther than that. Until ERIC crowds out rival cross-checking proposals across the country, there is a risk of another politicallymotivated inferior substitute gaining traction - especially in regions that are more prone to subscribing to the myth of voter fraud. Indiana's Crosscheck replica already exists, and may spread rapidly if Congress or the new administration do not take appropriate preventative measures. Now that there is a window of opportunity for desperately needed improvements in election administration, it must not be squandered.

\section{Proposals and Conclusion}

Crosscheck should not have been able to thrive the way it did. It experienced tremendous success, eventually including over a third of the country's population and a supermajority of its states - even a number of states under full Democratic control. This success came despite the fact that its function as a partisan tool was observable and its matching strategies were grossly inefficient. While there is an obvious and significant need for an interstate voter data cross-checking program, other programs like ERIC slowly surpassed Crosscheck in utility and cost-effectiveness starting in 2012; Crosscheck's successful recruitment later on in the mid-2010s is therefore attributable to serious policy missteps. First, there was no federally-supervised or federally-created data matching system included in the HAVA reforms, creating a dangerous vacuum.

Another error was neither subsidizing the costs of joining ERIC after its creation in 2012 nor using federal power to actively expand the program. A third fault lies with the Department of Homeland Security for not shutting the program down sooner as a data privacy risk, though that particular issue is beyond the scope of this paper. Those policy missteps need to be addressed immediately, as Crosscheck has only been suspended rather than entirely eliminated, and states like Indiana are setting up their own harmful reproductions of Crosscheck in the meantime.

For an easy first step, Crosscheck should not have benefited from an artificial boost relative to ERIC by being nominally "free;" this enabled unscrupulous actors to sway state policymakers toward Crosscheck. Once states discovered the huge unstated cost of processing the data, many dropped out and refused to do anything with the results they received. Therefore, federal subsidies may be used to immediately counterbalance the 
costs of participating in ERIC, as the organization's up-front costs are a deterrent to new membership. Based on ERIC's current structure, it would cost $\$ 500,000$ to pay the remaining 20 states' initial fees; while the federal government does not regularly pay for the administration of elections, this could be a useful down payment similar to other subsidies and grants offered in the past. The total cost for all states' annual dues, which range between $\$ 25,000$ and $\$ 50,000$ to account for the different sizes of states, would range between $\$ 1.2$ million and $\$ 2.5$ million annually. While a significant sum, the expense is relatively small and particularly cost-effective compared to the hundreds of millions of dollars expended annually by the federal government on HAVA grants and special grants, like those in the CARES Act.

Theoretically, ERIC could even be incorporated into a formal public-private partnership with the federal government: it could work directly with the Election Assistance Commission (EAC), which has been asked to take a larger role in state-tostate information sharing in the past (Election Reform 2006, 21). Such a step would also enable federal oversight, an important consideration for state adoption in light of Crosscheck's glaring data risks and the partisan showdown over implementing ERIC in Wisconsin. However, putting ERIC - currently independent from most political influence as a not-for-profit nongovernmental organization-under the federal aegis would also pose new challenges, like potential meddling by political appointees. This has been a problem with the EAC in the recent past, with an executive director interceding against initiatives to improve election cybersecurity and being accused of overdeference to a GOP commissioner (Geller 2019). If a future administration is able to politicize the data-matching, just as was done with Crosscheck, the trade-offs of any prospective public-private relationship should be carefully evaluated.

Ideally, federal interstate data-matching guidelines would have been created upon the passage of HAVA in 2002. That did not happen, so now that ERIC exists as a reasonably pragmatic substitute, that system must be expanded to include every state in the country. By fully occupying that space, its presence could crowd out any serious further consideration by partisan actors of a subpar alternative like Crosscheck. States may accomplish this on their own, but this is again an area where federal facilitation would greatly stimulate bandwagoning and shore up the program. Given the window of opportunity for federal action on election administration that has been opened as a result of the 2020 election and its aftermath, Congress and the new administration would be wise to act strongly on this issue and prevent future worries about interstate datamatching as our society grows ever more mobile and digital; that extra time could then be spent productively on other matters in our elections like protecting voting rights and considering ranked-choice voting proposals.

The field of voter list maintenance is at an unstable equilibrium; while ERIC has significantly improved this aspect of election administration, and it has been adopted by a wide majority of states, there are still very few guardrails preventing the possibility of future disruption by another partisan-oriented cross-checking entity. Crosscheck's ascent was a direct result of an unsupervised environment, and new partisan projects like Indiana's Crosscheck replica continue to arise and pose new risks to public trust in American elections. Policymakers must grow ERIC further and evaluate an appropriate degree of federal involvement if they hope to maintain a 
consolidated, professional, national data matching regime and to improve this vital component of the election administration landscape.

\section{References}

American Center for Voting Rights Legislative Fund. 2005. Vote Fraud, Intimidation \& Suppression in the 2004 Presidential Election.

https://www.foxnews.com/projects/pdf/Vote_Fraud_I ntimidation_Suppression_2004_Pres_Election_v2.pd f.

Barakat, Matthew. 2013. "VA removes 40K from voter rolls over Democrats' objections." Richmond Times-Dispatch, October 17, 2013.

https://www.richmond.com/news/state-regional/varemoves-k-from-voter-rolls-over-democratsobjections/article_2d111de4-49de-523b-bd9c$5 \mathrm{~d} 93 \mathrm{~b} 7 \mathrm{c} 0 \mathrm{a} 00 \mathrm{e} \cdot \mathrm{html}$.

Berman, Ari. 2017. "The Man Behind Trump's Voter-Fraud Obsession." The New York Times Magazine, June 13, 2017.

https://www.nytimes.com/2017/06/13/magazine/theman-behind-trumps-voter-fraud-obsession.html.

Brater, Jonathan. 2013. "Virginia Offers Lessons for Voter List Maintenance." Brennan Center for Justice, November 25, 2013.

https://www.brennancenter.org/our-work/researchreports/virginia-offers-lessons-voter-listmaintenance.

Bland, Gary and Burden, Barry C. 2013. Electronic Registration Information Center (ERIC), Stage 1 evaluation, Report to the Pew Charitable Trusts. Research Triangle Park, NC: RTI International. https://www.rti.org/publication/electronicregistration-information-center-eric-stage-1evaluation-report-pew-charitable.

Bruzek, Alison. 2017. "Mass. Ended Its Participation In Controversial Voter Fraud System In March." WBUR, November 7, 2017. https://www.wbur.org/radioboston/2017/11/03/massa chusetts-crosscheck-system.

Cameron, Dell. 2018. "Eighth State Quietly Quit Free Anti-Voter-Fraud Program Over Security Concerns and 'Unreliable' Results." Gizmodo, January 29, 2018. https://gizmodo.com/eighth-state-quietly-quitfree-anti-voter-fraud-program-1822514538.
DiStaso, John. 2018. "Exhaustive investigation reveals little evidence of possible voter fraud in NH." WMUR9, May 29, 2018.

https://www.wmur.com/article/exhaustiveinvestigation-reveals-little-evidence-of-possiblevoter-fraud-in-nh/20955267.

Election Reform: What's Changed, What Hasn't, and Why, 2000 - 2006. 2006. Pew Charitable Trusts. https://www.pewtrusts.org//media/legacy/uploadedfiles/wwwpewtrustsorg/report s/election_reform/electionline022006pdf.pdf.

Ellis, Atiba R. “The Meme of Voter Fraud.” 2013. Catholic University Law Review 63: 879-916.

Esau, Keith. 2017. "Interstate Voter Registration Crosscheck Program." Presentation to the National Conference of State Legislatures, June 15, 2017. https://www.ncsl.org/Portals/1/Documents/Elections/ Kansas_VR_Crosscheck_Program.pdf

Frank, Thomas. 2007. What's the Matter with Kansas?: How Conservatives Won the Heart of America. Picador.

Geller, Eric. 2019. "Federal election official accused of undermining his own agency." POLITICO, June $15,2019$.

https://www.politico.com/story/2019/06/15/federalelection-brian-newby-2020-1365841.

Gerhart, Ann. 2021. "Election results under attack: Here are the facts." Washington Post, March 11, 2021.

https://www.washingtonpost.com/elections/interactiv e/2020/election-integrity/.

Gitlin, Adam and Wendy Weiser. 2017. The Justice Department's Voter Fraud Scandal: Lessons. Brennan Center for Justice, January 6, 2017. https://www.brennancenter.org/our-work/researchreports/justice-departments-voter-fraud-scandallessons.

Goel, Sharad et al. 2020. "One Person, One Vote: Estimating the Prevalence of Double Voting in U.S. Presidential Elections." American Political Science Review 114, no. 2: 456-469, https://5harad.com/papers/1p1v.pdf.

Hasen, Richard L. 2012. The Voting Wars: From Florida 2000 to the Next Election Meltdown. Yale University Press.

Hayward, Mark. 2020. "Madison man, 81, admits to voter fraud." New Hampshire Union-Leader, January 


\section{3, 2020.}

https://www.unionleader.com/news/crime/madisonman-81-admits-to-voter-fraud/article_49e64e6db992-53fe-994e-0020ff98311c.html.

Hearne, Mark. 2005. Testimony to the House of Representatives Committee on House Administration, March 21, 2005. https://web.archive.org/web/20050324134715/http:// www.ac4vr.com/news/testimony.html.

Hegeman, Roxana. 2019. "Multistate Voter Database Suspended in Lawsuit Settlement." Associated Press, December 10, 2019.

https://apnews.com/article/2c82eb782e578bbb81c121 ec453fbee8.

Huseman, Jessica. 2017. "Election Experts See Flaws in Trump Voter Commission's Plan to Smoke Out Fraud." ProPublica, July 6, 2017.

https://www.propublica.org/article/election-expertssee-flaws-in-trump-voter-commissions-plan-tosmoke-out-fraud.

"Inaccurate, Costly, and Inefficient: Evidence That America's Voter Registration System Needs an Upgrade.” 2012. Pew Charitable Trusts. https://www.pewtrusts.org/en/research-andanalysis/reports/2012/02/14/inaccurate-costly-andinefficient-evidence-that-americas-voter-registrationsystem-needs-an-upgrade.

"Iowa joins three neighboring states in voter registration deal." 2005. Associated Press, December 12, 2005.

http://global.factiva.com/redir/default.aspx? $\mathrm{P}=$ sa\&an $=$ APRS000020051212e1cc002yc\&cat=a\&ep=ASE.

Johnson, Shawn. 2021. "Wisconsin Supreme Court Rejects Voter Purge Lawsuit." Wisconsin Public Radio, April 9, 2021.

https://www.wpr.org/wisconsin-supreme-courtrejects-voter-purge-lawsuit.

Kingdon, John. 1995. Agendas, Alternatives, and Public Policies. New York: Harper Collins.

Kirby, Brendan. 2017. "Study: Seven Million Voters Registered in Multiple States." LifeZette, May 19, 2017. https://www.lifezette.com/2017/05/studyseven-million-voters-registered-in-multiple-states/.

Leave Crosscheck. 2019. "Breaking: Illinois becomes the ninth state to withdraw from Kansas-run Crosscheck.” January 22, 2019. https://www.leavecrosscheck.com/blog/2019/1/22/br eaking-illinois-becomes-ninth-state-to-withdrawfrom-kansas-run-crosscheck.

Leave Crosscheck. 2020. Copy of CrossStateCheckStatistics 2017.xlsx. October 2, 2017.

https://drive.google.com/file/d/0B5XYKw4YT8ObN U1hVHZtYy0yUTA/view

Lee, Suevon and Sarah Smith. 2016. "Everything You've Ever Wanted to Know About Voter ID Laws." ProPublica, March 9, 2016.

https://www.propublica.org/article/everything-youveever-wanted-to-know-about-voter-id-laws.

Lefler, Dion. 2019. "Bills target Kobach's voter fraud legacy; 3 1/2 years, no illegal immigrants caught," The Wichita Eagle, January 20, 2019, https://www.kansas.com/news/politicsgovernment/article224722135.html.

Lerner, Kira. 2018. "Kobach is prosecuting this confused senior with four counts of felony voter fraud." ThinkProgress, January 5, 2018, https://archive.thinkprogress.org/kobach-fraudcharge-1eefa6b469d3/.

Levitt, Justin. 2007. The Truth About Voter Fraud. Brennan Center for Justice, November 9, 2007. https://www.brennancenter.org/our-work/researchreports/truth-about-voter-fraud.

Lowe, Peggy. 2017. "Kansans Caught In Crosscheck System Singled Out For Kobach's Voter Fraud Campaign.” KCUR 89.3, February 7, 2017. https://www.kcur.org/politics-elections-andgovernment/2017-02-07/kansans-caught-incrosscheck-system-singled-out-for-kobachs-voterfraud-campaign.

Lowry, Brian and Hunter Woodall. 2017. "Unsealed documents show Kobach urged Trump to change federal voting law." McClatchy DC, October 9, 2017. https://www.mcclatchydc.com/news/politicsgovernment/election/article177413031.html.

Mann, Brian. 2006. Welcome to the Homeland: A Journey to the Rural Heart of America's Conservative Rebellion. Steerforth Press.

Miller, Jim. 2014. "Millions of Californians missing from the registration rolls." The Sacramento Bee, May 29, 2014.

https://www.sacbee.com/news/politicsgovernment/election/article2598501.html. 
Minnite, Lorraine. 2015. "North Carolina State Conference of the NAACP v. McCrory, et al. U.S. District Court, Middle District of North Carolina. February 12, 2015.

https://cdn.theatlantic.com/assets/media/files/30cc80 b86094822ecb_1zm6b8108-2.pdf.

Minnite, Lorraine. 2010. The Myth of Voter Fraud. Ithaca: Cornell University Press.

"My voter registration was cancelled - will I be one of 350,000?" 2013. Blue Virginia, September 3, 2013. https://bluevirginia.us/2013/09/my-voterregistration-was-cancelled-will-i-be-one-of-350000.

Nolan, Jim. 2013. "Chesterfield registrar delays purge of voter rolls." Richmond Times-Dispatch, October 9, 2013.

https://www.richmond.com/news/local/chesterfield/c hesterfield-registrar-delays-purge-of-voterrolls/article_162e36b5-0be7-5dc8-af9f48876a167b43.html.

Office of the Kansas Secretary of State. 2006.

Canvassing Kansas, March 2006.

http://www.kssos.org/forms/communication/canvassi ng_kansas/march06.pdf.

Office of the Kansas Secretary of State. 2005. "Carnahan and Thornburgh Announce Multi-State Initiative to Clean Up Voter Rolls and Improve Election Security." December 13, 2005. https://cdm16884.contentdm.oclc.org/digital/collectio $\mathrm{n} / \mathrm{p} 16884$ coll18/id/4/rec/15.

Office of the Kansas Secretary of State. 2017.

"Interstate Voter Registration Data Crosscheck: 2017 Participation Guide.” January 2017.

https://static1.squarespace.com/static/599f1bf1d482e 92e416b7c50/t/59fe7e30ec212d4734a0c149/1509850 673473/Interstate + Crosscheck +2017 .pdf.

Palast, Greg. 2016. “The GOP's Stealth War Against Voters." Rolling Stone, August 24, 2016.

https://www.rollingstone.com/politics/politicsfeatures/the-gops-stealth-war-against-voters-247905/.

Palast, Greg. 2014. "Jim Crow Returns." Al Jazeera America, October 29, 2014.

http://projects.aljazeera.com/2014/double-voters/.

Pérez, Myrna. 2008. Voter Purges, Brennan Center for Justice, September 30, 2008.

https://www.brennancenter.org/sites/default/files/201 9-08/Report_Voter-Purges-2008.pdf.
Ramer, Holly. 2018. "N.H. database flags 142 possible voter fraud cases, not Trump's 'thousands." Concord Monitor, May 29, 2018. https://www.concordmonitor.com/Database-flags142-possible-voter-fraud-cases-17835841.

Rothschild, Scott. 2014. "Program run by Kobach checks voter registration records of more than 100 million people." Lawrence Journal-World, April 20, 2014.

https://www2.ljworld.com/news/2014/apr/20/progra m-run-kobach-checks-voter-registation-record/.

SB 34. Kansas State Legislature. Enrolled June 8, 2015.

http://www.kslegislature.org/li_2016/b2015_16/meas ures/sb34/.

SB 334. 121st Indiana General Assembly. Enrolled March 21, 2020.

http://iga.in.gov/legislative/2020/bills/senate/334\#doc ument-f7b66d04.

SB 795. 84th Texas Legislature. Enrolled June 15, 2015.

https://capitol.texas.gov/BillLookup/History.aspx?Le gSess $=84 R \&$ Bill=SB795.

Shaw, Daron, Stephen Ansolabehere, and Charles Stewart III. 2015. "A Brief Yet Practical Guide to Reforming US Voter Registration Systems." Election Law Journal 14, no. 1: 26-31.

Shipan, Charles R., and Craig Volden. 2008. "The Mechanisms of Policy Diffusion." American Journal of Political Science 52, no. 4: 840-57. http://www.jstor.org/stable/25193853.

"State Partisan Composition.” 2020. National Conference of State Legislatures, March 31, 2020. https://www.ncsl.org/research/about-statelegislatures/partisan-composition.aspx.

Stegmaier, Mary and John Lindback. 2017. "Trump wants voter registration investigated. This is how 20 states are already doing it." The Washington Post, January 30, 2017. https://www.washingtonpost.com/news/monkeycage/wp/2017/01/30/trump-wants-voter-registrationsinvestigated-but-theres-already-a-system-for-that/.

Texas Senate Committee on State Affairs. 2015. Video recording of public hearing. April 13, 2015. 84th Texas Legislature.

https://tlcsenate.granicus.com/MediaPlayer.php?view _id=30\&clip_id=9664. 
United States Department of Justice, Office of the Inspector General and Office of Professional Responsibility. 2008. An Investigation into the Removal of Nine U.S. Attorneys in 2006. https://oig.justice.gov/special/s0809a/final.pdf.

Young, Frank W. 2013. "“What's the Matter With Kansas?" A Sociological Answer." Sociological Forum 28, no. 4: 864-872.

Zeff, Sam. 2019. "FBI Documents: Kobach Hired A Criminal Investigator With No Law Enforcement Experience." KCUR 89.3, October 29, 2019. https://www.kcur.org/politics-elections-andgovernment/2019-10-29/fbi-documents-kobachhired-a-criminal-investigator-with-no-lawenforcement-experience 